Article

\title{
Rootedness, Activism, and Centralization: The Case of the Swiss People's Party
}

\author{
Adrian Favero \\ Department of Political Science and International Studies, University of Birmingham, UK; E-Mail: a.v.favero@bham.ac.uk
}

Submitted: 9 May 2021 | Accepted: 2 August 2021 | Published: 24 November 2021

\begin{abstract}
The Swiss People's Party (Schweizerische Volkspartei [SVP]) has increased its territorial extensiveness and organizational intensiveness in recent years, and has professionalised its strategies of communication. This article analyses the dynamics characterising the SVP's organization. It shows that with its locally rooted presence and its effort to generate ideological coherence, the party has embraced the "mass party" organizational model. It additionally assesses the extent to which the SVP's centralised power at the federal level is conducive to the party's further electoral success. Having considered both the party at national level and three of its most important cantonal branches, the article argues that the organizational dominance of the SVP's central leadership was beneficial for the party's electoral strength but will lead to tensions with cantonal and local branches, which are largely in charge, to build and maintain an active base.
\end{abstract}

\section{Keywords}

activism; centralization; mass parties; Swiss People's Party

\section{Issue}

This article is part of the issue "Right-Wing Populist Party Organisation Across Europe: The Survival of the Mass-Party?" edited by Daniele Albertazzi (University of Surrey, UK) and Stijn van Kessel (Queen Mary University of London, UK).

(C) 2021 by the author; licensee Cogitatio (Lisbon, Portugal). This article is licensed under a Creative Commons Attribution 4.0 International License (CC BY).

\section{Introduction}

Current academic literature describes the Swiss People's Party (Schweizerische Volkspartei [SVP], also known as Union démocratique du centre [UDC]) as one of the largest and most successful populist radical right parties (PRRPs) in Western Europe (Stockemer, 2018). The party has benefited from organizational and ideological changes implemented by the charismatic leader of its Zurich branch, Christoph Blocher, throughout the 1980s and 1990s. In subsequent years these were adopted by cantonal party branches in other areas of the country. Like many successful PRRPs, the party now relies on a centralized organization that allows the national leadership to exercise considerable influence (Mazzoleni \& Rossini, 2016, p. 100). Moreover, given the party's reliance on a strong central bureaucracy and around 80,000 party members, as well as its ability to socialize its members into politics and shape their views, it can legitimately be assumed to feature certain aspects of a "mass party" in the sense embraced by this thematic issue. These aspects include a centralized organization, the recruitment of a large activist membership base, a broad presence on the ground, and a wide range of activities provided to the grassroots, as well as the creation of a collective identity based on a shared ideological view.

Following this introduction and a brief section covering the recent history of the party, this article will discuss the features of the SVP's organization, as well as the party's focus on developing an active membership base (Section 3). Here, and in line with the objectives of this thematic issue, I explain which features the SVP adopted from the mass party model. Following on from this, I consider the extent to which power has been centralized within its organization, and how much influence members may be said to exercise today on its strategies and ideology. The article argues that members have limited power to influence key decision-making processes initiated by leadership at cantonal and federal levels, and that the current highly centralized organization could 
lead to problems between the party's national organization and its sub-national branches. Such problems may include a lack of influence of cantonal branches at the national level (see representatives 14, 15, and 18, in the Supplementary Material), top-down decisions on topics that do not resonate with local needs or new members (see representatives 3,6, and 19, in the Supplementary Material), or campaigns that are seen as too controversial among potential voters (representative 11) or in certain regions (representative 27). As a representative (15) from rural Bern outlined:

For us here in the country side, the Zurich wing is extreme and difficult. The [Zurich branch's ideology] is not our ideology but the leadership is from there....We need a leadership who is not stubborn and has a narrow view, but can work with others. I think that is the way to win more members.

In terms of its methodology, this study benefits from a series of 32 structured interviews (see Supplementary Material for the list of interviewees) with SVP national and cantonal representatives (the latter from the cantons of Zurich, Bern, and Geneva). The representatives occupy different roles and responsibilities within the SVP, ranging from presidents of local sections to members of the national parliament. The answers provided by these representatives offer a comprehensive insight into the SVP's attempts to create a mass party and the party's organizational structure. This research also draws on the study of party documentation, such as party statutes (SVP Bern, 2019; SVP Schweiz, 2018; SVP Zürich, 2019; UDC Genève, 2018), and the party programme (SVP Schweiz, 2019a).

The choice of these cantonal branches is justified by the distinct role they played for the SVP's political development. Bern represents the "old SVP," which dominated the party until the 1980s and has been a rather centrist governmental party (Mudde, 2007). In Zurich, the "new SVP" (Mazzoleni, 2008) has developed a more oppositional and conservative profile and took over the national SVP during the 1990s. Geneva is important as an example of a French-speaking area into which the SVP only expanded recently. I consider the nature of the party's organization in some detail once its history has been briefly summarized in the next section.

\section{The Swiss People's Party: A Historic Overview}

According to Ladner (2006), Swiss national parties have a relatively weak position within the state and the society. The reasons for their weak standing are the characteristic idiosyncrasies of Switzerland and its political system, such as the social and culturally heterogeneous structure, the existence of four different language groups, strong federalism, the small size of the country, and a political system with predominantly non-professional representatives (militia system). Within this system, it is difficult to build a centralized national party organization, and Swiss parties adapted to this system by creating relatively autonomous cantonal branches.

Additionally, Kriesi et al. (2005) describe the Swiss party system as "frozen," with the four biggest parties - the Liberals (FDP.Die Liberalen [FDP]), the Social Democratic Party (Sozialdemokratische Partei der Schweiz [SP]), the Christian Democratic People's Party (Christlichdemokratische Volkspartei der Schweiz [CVP]), and the SVP-sharing governmental responsibility among the seven members of the Federal Council according to the magic formula, established in 1959, in which the four major parties have two (FDP, CVP, SP) or one (SVP) seat in accordance with their share of the vote. This formula (that changed after 2003, with the SVP gaining an additional seat and the CVP losing its second seat) and the collegiality system based on consensus in the Federal Council prevented the development of a real opposition party:

"The Federal Council reaches its decisions as a collegial body" states the Federal Constitution. Decisions are taken jointly. All Federal Council members must stand by the decisions in their external dealings, even if a decision may not accord with their personal views or the policy of their party. (Federal Council, 2020)

Therefore, the governing structure was instrumental to Switzerland's political stability and consensual system (Mazzoleni \& Skenderovic, 2007). Moreover, the vote shares of these four largest governing parties did not change substantially between 1919 and 1995 (Ladner, 2006). However, this stable system was about to change fundamentally: With the arrival of a new party leadership in 1990s, the SVP developed a distinct vote-seeking strategy, and experienced organizational growth and electoral success (Mazzoleni \& Rossini, 2016).

The origins of the SVP can be traced back to 1917, when the so-called Farmers' Party was founded in the canton of Zurich. Only a few years later, in 1936, the national party was founded under its new name: Farmers, Artisans and Citizens Party. The purpose of the party was the defense of rural interests against the urban-dominated liberals (Kriesi et al., 2005; Mazzoleni \& Skenderovic, 2007). In 1971, the SVP was founded when the Farmers, Artisans and Citizens Party merged with the Democratic Party from the cantons of Grisons and Glarus (Mazzoleni \& Rossini, 2016). Under the lead of the SVP's Zurich branch, the party then managed to establish a nationwide presence. Yet the political dominance of SVP Zurich also led to internal conflicts between cantonal branches.

While both the Zurich and Bern branches have deep agrarian roots, ideological differences between the two have become very noticeable. Bern stuck to a more moderate, conservative line, while Zurich developed a more radical profile as a populist radical right organization. Contrary to the well-established branches from Bern and 
Zurich, in Geneva the SVP could not rely on an established organizational structure (representative 8) and, to date, remains relatively small. As for its ideology, in contrast to SVP Bern, the SVP branch in Zurich took an aggressive opposition course advocating for more law and order, and restricting integration into international communities. This course was also joined by SVP Geneva, which had initially taken a more liberal stance (Kriesi et al., 2005).

Scholars who have discussed the radicalization of the party (e.g., Skenderovic, 2009) highlight the crucial role played by Christoph Blocher. Elected president of the party's Zurich branch in 1977 (a position he held until 2003), Blocher turned a formerly conservative party rooted in rural areas into a successful PRRP able to target urban voters. As a strong, charismatic leader of an initially weak organization (Mudde, 2007), Blocher "achieved a sort of 'godfather' status" (Bernhard, 2017, p. 515). The party also paved the way for Blocher to return to the national leadership after he lost his seat in the Federal Council (Albertazzi \& McDonnell, 2015). In 2008, President Toni Brunner approached Blocher and urged him to become one of the vice-presidents in the Head Office, for which the party had to expand its leadership committee (Mazzoleni \& Rossini, 2016).

Blocher himself is aware of his firm authority within the party organization despite never serving as party president. In an interview held in October 2020, he claimed: "On certain issues, I had more influence than the president... because [referring to himself] there simply was a politician with great charisma, well, from the viewpoint of others." Indeed, Blocher was widely assumed to play an important role in the appointment of party presidents, while he also made final decisions and dominated the party organization from his residence in Herrliberg. However, several representatives emphasized that although Blocher was crucial to the party in the past when he was more active, at present the SVP is no longer dictated to by his strong influence (see representatives 5 and 33).

By creating the new SVP in the 1990s, Blocher's organizational strategy was fourfold (Albertazzi \& McDonnell, 2015, pp. 55-56), and aimed to make the party more centralized, efficient, and electorally appealing. Firstly, Blocher pushed for territorial expansion and facilitated the establishment of party branches in areas the party had not reached before. These, in turn, followed the example of the Zurich branch, as they aimed to run their organizations professionally and bought into Blocher's populist radical right ideology (Skenderovic, 2009). Secondly, Blocher supported the idea of changing the party's statute so that more power (for instance within the Delegate Assembly) would be given to the most electorally successful cantons. Such a system is like those employed by the other large parties who assign cantonal delegates according to seats in the national parliament (FDP), number of members in cantonal branches $(\mathrm{SP})$, or a mix of voter turnout and members (CVP).
In the case of the SVP, this system allowed party representatives from Zurich to ultimately gain control of the party's main ruling body. Thirdly, in 2004 the party strived for greater centralization and vertical integration by strengthening the role of the Central Committee and the National Central Office (Mazzoleni \& Rossini, 2016). In the meantime, its campaigns were professionalized (for example, by hiring external companies to help with them), while benefiting from Blocher's own financial support as a wealthy businessman.

Besides renewing its organization to make it more efficient and centralized, the SVP also strove to achieve more coherence in ideological terms. Hence, by the 1990s, the party was said to have devised a new "winning formula" (Mazzoleni \& Skenderovic, 2007), which combined an emphasis on nationalism and "traditional values" with market-friendly proposals on the economy and taxation. In pure populist style, the party also positioned itself as the lone opponent of a classe politique (political establishment; Hildebrand, 2017) allegedly composed of all other parties in the country, regardless of their ideological orientation. Adding nativism to a newly adopted populist agenda, the SVP also focused on issues having to do with migration, asylum seeking, and European integration.

The democratic tools available in the Swiss political system allowed the SVP to use referendums and initiatives as an effective instrument to promote its own agenda during the 1990s and 2000s. Most notably, the SVP, together with Blocher's AUNS (the Campaign for an Independent and Neutral Switzerland; Blocher was one of its founders and its president from 1986 until 2004) employed substantial financial and ideological resources to oppose the country's participation in the European Economic Area, which resulted in a narrow win (50.3\% against entry; Albertazzi, 2008). The SVP continued to launch campaigns, often with the goal of showing its anti-establishment attitude and pushing the party's key topics. One example is the popular initiative on a nationwide ban on the construction of minarets, which the party won in November 2009. The question on minarets fitted well into the SVP's strategy to emphasize symbolic nativism and Swiss traditional values (Betz, 2013).

The organizational strategies mentioned above, as well as the party's focus on new themes, helped it become more efficient and ideologically coherent. As a result, the SVP enjoyed continuous electoral gains from the mid-1990s to 2007 and remains the largest political party in the country today in terms of vote share. Furthermore, with its strategy, the SVP managed to win over considerable parts of the working class that traditionally voted for the SP (Rennwald \& Zimmermann, 2016). As Figure 1 shows, since 2003, the party has enjoyed the support of over $25 \%$ of voters in federal elections, from a low point of $10 \%$ during the pre-Blocher era (Swiss Federal Statistical Office, 2019). Because of this success, in 2003 the party increased its representation in the seven-strong Federal Council-i.e., 


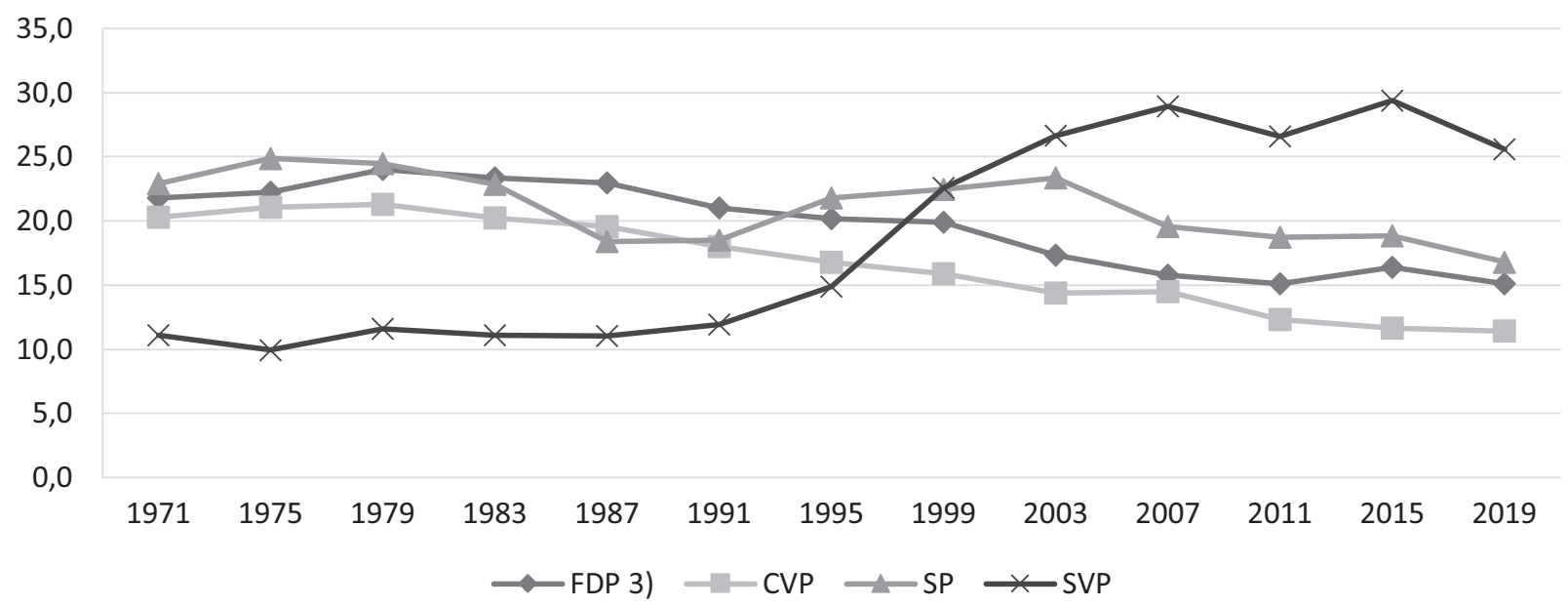

Figure 1. The voters share of the four biggest parties in the National Council, 1971-2019. Source: Swiss Federal Statistical Office (2019).

the country's executive-and Blocher himself became a Federal Councillor.

Despite the party's electoral and governmental successes, a "third phase in the SVP's evolution" (Mazzoleni \& Rossini, 2016, p. 92) started in 2007 that posed new challenges to the party's cohesion. In December of that year, the Parliament decided not to reappoint Blocher as Federal Councillor and replaced him with a more moderate SVP member, Eveline Widmer-Schlumpf, against the wishes of their party. Blocher's ejection-justified by the other parties with reference to his alleged unwillingness to compromise and support the executive in publicled to a split in the SVP. As some moderate cantonal branches were expelled by the national organization for supporting Widmer-Schlumpf, they proceeded to found a new conservative party, The Conservative Democratic Party of Switzerland (Bürgerlich-Demokratische Partei Schweiz; Bernhard, 2015), which both SVP government representatives decided to join. Hence, for a brief period, the SVP found itself in opposition, something unprecedented in a country in which all the largest political parties always share government responsibilities. While the SVP was able to return to government after a few months, it responded to the risks of experiencing more internal factionalism by centralizing its organization further and by holding on to a radical ideological profile.

The SVP's ability to adapt its organizational structures and refocus its message to respond to internal challenges may be tested again soon. Following some electoral losses in 2019, the party's leadership has identified insufficient mobilization of its members and internal disputes between cantonal branches as problems to be urgently addressed. A solution proposed by the leadership has been to better connect the leaders with the grassroots (SRF, 2019a), suggesting that the party will invest even more in what has widely been seen as a key feature of the mass party: rootedness on the ground, the existence of vibrant local party branches and activities, and the deployment of mechanisms of value-infusion and socialization of members, such as the ones described in the next section.

\section{Building and Maintaining the Mass Party}

To evaluate the extent to which the SVP fits the mass party model, I now explore the party's organization (including the power of different bodies and offices within the party), and how it attracts members and fosters activism (including the role played by social media).

The four largest Swiss parties are not organizationally structured in the same way. Their bodies differ in name, size, tasks, and responsibilities, as well as the influence of their members. For example, the SP and the SVP grant only representatives from the largest cantonal branches direct access to their national party committees, whereas the FDP and the CVP invite the presidents of all cantonal branches. Nevertheless, all parties have in common that they describe their respective Delegate Assembly as the party's supreme body (CVP Schweiz, 2020; FDP Schweiz, 2020; SP Schweiz, 2020a; SVP Schweiz, 2018).

According to their statutes (SVP Schweiz, 2018) the SVP maintains a rather complex organization. Since 2016, the main bodies have been the Delegate Assembly (Delegiertenversammlung), the Party Committee (Parteivorstand), the Head Office (Parteileitung), and the Party Executive Committee (Parteileitungsausschuss). At the national level, the Party Executive Committee consists of nine people and acts as a central body taking care of day-to-day business and communication. The Head Office consists of 29 members. The six cantons with the largest electorate and one representative from the French-speaking, from the Italian-speaking, and Romansh-speaking parts of Switzerland have a seat on this body, among other representatives. It advises on current political issues and coordinates the work of various offices and bodies within the party. Moreover, this body is also responsible for the development of programmatic 
proposals, which are subsequently discussed (and eventually approved) by the Party Committee. While this structure should ensure broader cantonal support for strategic party work, in practice it also guarantees that the largest cantons continue to exercise considerable influence on the party's strategies and proposals. The Party Committee is made up of 128 members who pass resolutions on launching referendums, approve the annual report, and elect members of the Head Office. Finally, the Delegate Assembly is regarded as the supreme party body and consists of 840 delegates from the cantonal sections. This body retains the power to elect party leaders, decides on the position the party should take on the (frequent) referendums held in the country, and approves any changes to its statute.

Moving down to the sub-national level, I find that the cantonal branches' organizations are characterized by many similarities in the way that they are structured (SVP Bern, 2019; SVP Schweiz, 2018; SVP Zürich, 2019; UDC Genève, 2018). Like the national level, the organizational backbone of each cantonal branch consists of a small Head Office, a Party Committee, and a Delegate Assembly. Importantly, these entities possess a certain degree of autonomy vis-à-vis the centre, as far as the setting of political strategies and the coordination of party members are concerned (Mazzoleni \& Rossini, 2016). The Head Offices hence discuss and shape the strategy and day-to-day business of the party, ultimately exercising considerable influence in developing cantonal strategies and positions before any other organ gets involved in their discussion. Party Committees often deal with organizational matters, such as preparing the Delegate Assembly, and managing the memberships. Finally, delegate assemblies make the final decisions on launching referendums or initiatives, approving manifestos and statutes, and electing members of organizational bodies. Although they are defined as the supreme party organ able to shape the party's programme and statutes, the members' delegate assemblies are in fact only marginally involved in preliminary decision-making processes and policy formulation. Delegates sometimes disagree with representatives and they may use the opportunity to provide their opinion publicly during the assembly, but eventually, they often approve of the party leadership's suggestions.

The SVP's smallest units are known as "local parties" (Ortspartei) or "local sections" (Sektionen/Sections communales). They are necessary to achieve rootedness on the ground and allow party representatives to become aware of local issues. The size of local branches varies widely, from a few members to several hundreds, depending on their location. Like all parties in Switzerland, the SVP has a network of local sections available. There are over a thousand local sections, but the party has yet to tap its full potential in French-speaking Switzerland (see representatives 2,14, and 21), where branches tend to be smaller. However, the number of the SVP's local sections is larger than those of the SP (805) but smaller than those of the FDP (1500). All numbers were obtained from party secretariats in 2020. No numbers were available for the CVP.

In sum, the SVP has increased the complexity and strength of its organization at the national level to ensure efficiency in executing the party's strategy. With its strongly centralized organization, the party preserves an extensive structure with an institutionalized local presence aiming to develop active grassroots following that resembles the mass party organizational model (Mazzoleni \& Rossini, 2016). Nevertheless, the networks of cantonal and local branches have retained some considerable powers, especially regarding the mobilization and coordination of party supporters. In the next section, I explore how the SVP attempts to utilize its rooted organization and means of communication to recruit more members.

\subsection{Attracting New Members and Reaching Out to the Public}

A key aim of any mass party is to grow a large active membership. This allows the party to shape the views of those who have joined the organization through a variety of means to then draw resources (e.g., membership fees, time and/or expertise) from large numbers of people. With 80,000 official members, the SVP is the third largest party in Switzerland in terms of membership. The FDP with 120,000 members and sympathizers, and the CVP with around 100,000 members are both larger in size, whereas the SP is significantly smaller with 33,000 official party members (all numbers directly obtained from party secretariats in 2020). This section considers the incentives offered by the SVP to those who may be thinking of joining, how the party reaches out to potential members, and the extent to which its activities may be said to follow the logic of the mass party.

To attract members and voters, the SVP has focused on several issues in its communication and campaigns: EU integration and "uncontrolled" immigration (both of which it opposes), the market economy, and helping the middle class (see representatives $2,13,14$, and 26). Moreover, the party strives to protect alleged "Swiss values," such as self-determination, independence, and freedom (SVP Schweiz, 2019a)-values apparently forgotten by the classe politique in Bern. Since radicalizing its ideology in the 1980s/1990s, the SVP has been able to offer a very clear message and distinctive values to voters that interviewed representatives see as an important reason why people join it today. However, some representatives mentioned that while these topics are important, the national leadership's aggressive style is sometimes seen as too provocative and disturbing by the grassroots (see representatives 3,25 , and 27).

In addition to this, the party also provides "communitarian" (Albertazzi, 2016) incentives to its members, as it is able to create close communities of like-minded individuals who end up feeling "at home" in the party. 
Party branches organise a wide range of events for their members to bind them to the organization, while claiming that, as a community, they are under attack, particularly from media organizations and left-wing parties. With these events, the party also creates opportunities for the celebration of "Swissness." Having focused much on identity matters in recent years, the SVP thus uses social events, such as the well-known Albisguetli convention (Albisgüetli-Tagung) organized every year by its Zurich branch, to celebrate what it sees as traditional Swiss values (Hildebrand, 2017). Moreover, to reach out to the public and be seen as approachable, the party also organizes activities called SVP With the People (SVP bi de Lüt). Here, constituents can speak to SVP representatives about local issues. In the words of most party representatives, personal contacts are invaluable to turn sympathizers into actual members, by showing that the party is willing to listen to and be approachable for ordinary folks. However, many interviewees mentioned that recruiting activists and members remains difficult (see representatives $10,16,27,28$, and 30 ). As a local representative from Zurich explained (16): "There is a large group who supports us, but they would probably never become members. This is the Zeitgeist. As it is in all associations, there is often no commitment."

As shown in this section, the local branches of the SVP provide the most direct linkage between the party and potential supporters, and the best way to connect with the public at large. By relying predominantly on social activities, canvassing, and personal communications, these branches aim to mobilize voters by offering them a clear message and ideology, as well as the opportunity to become part of a close community of activists. This is not to say that the party refrains from using new technologies (and particularly social media) to reach out to the public, and the next section will show how these are deployed both internally and externally. However, it certainly still believes in the importance of face-to-face communication too, for reasons that will be explored below.

\subsection{Online Communication and Social Media}

Online communication (and particularly social media) provides SVP representatives with means to convey their ideology as they see fit and without constraints (Engesser et al., 2017; Gerbaudo, 2018), hence allowing them to bypass the gatekeepers working for media organizations. This section investigates the SVP's deployment of online communication and how it is used to publicize the party's core message and maximize attention for its initiatives.

The SVP is active on Twitter, Facebook, and Instagram, yet with varying degrees of success compared to other governing parties (see Table 1). Except for the CVP, all parties have two official accounts, one for the Germanspeaking part of Switzerland and one for the Frenchspeaking part. The numbers show that the party's strongest social media presence is on Facebook. Despite being only the third largest party in terms of members, the SVP has many more followers than parties with a larger membership base, such as the CVP or the FDP. On Twitter, the SVP ranks only third among the governing parties, with notably fewer followers than the social democrats. Generally, the numbers illustrate that the four governing Swiss parties are not (yet) exploiting social media's full potential and instead focus predominately on traditional messaging and canvassing with face-to face interactions at the local level (Klinger \& Russmann, 2017).

One of the main purposes of the SVP's social media use is to clarify the party's position and distribute campaign messages prior to elections or federal referendums, with Facebook playing the most important role. As mentioned by representatives in interviews, the reasons for this are the platform's popularity and the fact that it has now achieved penetration even among older cohorts (representative 7). However, due to the number of older voters and members who still cannot be assumed to be familiar with any social media, emails and regular mail remain the most common means of direct communication with members and activists.

Overall, social media does not appear to play a crucial role yet for the SVP in recruiting members and creating communities of activists. Digital communication channels are mainly used to react to political developments and convey party ideology, but not very effectively to mobilize activists, as party representatives themselves readily admit (see representatives 4, 5, 17, and 19). Hence, personal contacts at the local level remain far more important for the purpose of recruiting new members and mobilizing them. These remain key aims of the SVP, for reasons explored in more detail in the next section.

Table 1. Number of social media followers of the four governing parties.

\begin{tabular}{llll}
\hline Party & Twitter & Facebook & Instagram \\
\hline SVP/UDC CH & $17,249 / 2,685$ & $30,937 / 12,041$ & $10,600 / 148$ \\
FDP/PLR CH & $18,779 / 4,718$ & $14,536 / 8,063$ & $4,889 / 1,229$ \\
SP/PS CH & $42,350 / 4,868$ & $28,700 / 6,490$ & $12,600 / 1,874$ \\
CVP CH & 16,463 & 14,534 & 2,932 \\
\hline
\end{tabular}

Source: Data collected by author, 24 November 2020. 


\subsection{Reasons to Grow an Active Base}

Mass parties rely on active supporters and a large membership base, and the SVP is no exception. Firstly, active members can be counted upon at election time (Scarrow, 2015) - a boost to any party in a country in which turnout tends to be low and people tend to either vote for the party they feel is very close to their views or abstain (SRF, 2019b). For instance, lack of mobilization was the main problem in the federal election of 2019, when the SVP lost 3.8 percentage points. After the election, representatives felt, the party needs to do better in terms of mobilizing its members; an active base was seen as a means to partially mitigate demobilization, particularly when debates do not revolve around the SVP's core topics (SRF, 2019a).

According to several interviewed representatives (see representatives $1,2,3,12,21$, and 31), active members and sympathizers are also essential to distribute the party's message and ideology. As a member (19) of the Cantonal Leadership Committee in Bern emphasized when asked about the main advantages of having active members: "The main reason is that we have more manpower and are more powerful. You can better convey your messages, you can campaign better, you can do better referendum battles." Another representative (31) specified that at the local level "we try to motivate members to convince other people that the SVP is needed. We try to motivate people to become messengers for our little section."

As is typical for a mass party, these grassroots-level activities of face-to-face "micro-campaigning" help disseminate the SVP's arguments and can arguably be more effective than the campaigns planned and executed from the top. However, this system also requires the identification of a set of topics with which members and sympathizers can identify (representative 1), and these need to be anchored in the Lebenswelt (life world) of party supporters for people to feel compelled to engage with them. In other words, local sections need to conduct "local politics," as I was told by a party representative (3). Indeed, some representatives told me that a lack of communication and linkage between the centre and the cantons, alongside an excessive focus on topics that do not necessarily resonate at the local level, have hampered the growth of a more active base in their local communities in recent years (see representatives 5, 6, 7, and 15).

While it aims to use members to campaign and connect to local people throughout the country, the national SVP does not particularly need them as a revenue source. The SVP's financial structure is unlike the classic massbased parties that gather small donations from a large group of members. According to the SVP's 2019 budget, only $3.7 \%$ of its income $(170,000 \mathrm{CHF})$ originates from membership fees from cantonal branches. (With the exception of Geneva, Neuchâtel, Ticino, Fribourg, and Schwyz, cantonal political parties are not required to disclose the sources or amounts of donations [OSCE,
2019]). The largest sources of income are donations, which make up $41.7 \%(1,900,000 \mathrm{CHF})$ of its projected income, and state contributions from the parliamentary group (46.73\%, 2,127,700 CHF; SVP Schweiz, 2019b). These findings are in line with Scarrow (2015), who argues that party members often have a comparatively small role in funding their parties. Unfortunately, comparisons with other parties are difficult as budget plans are not usually publicly available. The SP is the only other of the four governing national parties that published its budget. The largest sources of income are donations and fundraising (49\%, 3,229,211 CHF), and membership and solidarity fees $(32.5 \%, 2,144,512 \mathrm{CHF})$. The numbers show that the party relied more on membership fees in 2019 than the SVP (SP Schweiz, 2020b).

In sum, the SVP invests in creating an active base of supporters who are socialized into the party's key values and support it in a variety of ways, although recruiting new members-especially young people (see representatives 3,13, and 16)-and motivating existing members to become more active are challenges the party needs to address (see representatives 5, 6, 13, 19, and $32)$. As representative 13 said: "It is always the same few people who do something, who organize, who help." The next section considers the party's internal democratic processes and considers whether the SVP's focus on its members translates into the latter's empowerment. To what extent are members able to contribute to setting the strategy and message of the organization they belong to?

\section{Centralization of Power and Internal Functioning}

In a decentralized political system such as Switzerland, the extent to which national leaders can concentrate power into their hands vis-à-vis the party's cantonal branches remains a matter of contention (Mazzoleni \& Rossini, 2016). Below I consider the extent to which the SVP has centralized decision-making since 2016, and the extent to which members can influence decisions taken by their party.

As I have mentioned above, Blocher is widely acknowledged to have reinvented the SVP, turning it into a PRRP. The Blocher-inspired radicalization of the party's message in the 1990s went hand in hand with the increasing centralization of power in the hands of the national leadership. The Central Committee acquired more responsibilities, and the electorally more successful cantonal branches were granted more delegates in the National Delegate Assembly, as well as seats in the Head Office. In this period, the party's message was also made more coherent and directed from the centre with the help of professional communicators. From 2016 onwards, the SVP went through a process of further centralization by creating a Party Executive Committee (Parteileitungsausschuss) responsible for the party's daily business and organizing national campaigns. The new organizational structure allowed for 
more efficient management of the party and centralized control of its communication, as the Party Executive Committee speaks on behalf of the party at national level. A representative from the national leadership emphasized that this structure ensures that "the party speaks with one voice" (representative 2).

However, the party's cantonal leaders maintain a crucial role, insofar as cantonal branches still possess full legal and organizational autonomy within the framework of the national statute. Yet this level of autonomy does not mean that they can necessarily exercise the same influence at the national level. Cantonal branches are considered the "organizational foundation of the SVP Switzerland" (SVP Schweiz, 2018), yet some cantons are visibly more influential than others on national matters (representative 14). As a case in point, since the 1990s, the presidents of the six electorally most successful cantonal branches of the party enjoy membership of the national Head Office. This gives them an opportunity to contribute to setting the strategy of the party. In this respect, leadership and organization of the cantonal branches are of specific importance to fostering an active base because they grant leverage at the national level and direct access to prior deliberations.

Notwithstanding this imbalance, the recent tendency towards the concentration of power in the hands of a restricted party elite has thus been mitigated by the features of Swiss political culture and the country's institutions. The party's cantonal and local branches have retained some degree of autonomy due to the highly decentralized political system, which means that complete internal and external coherence and absolute dominance of federal party organs over cantonal branches remain out of reach. Indeed, programmatic differences between national and cantonal branches of the party are common (Storz \& Bernauer, 2018), and cantonal branches sometimes deviate from national voting recommendations, depending on intra-cantonal cleavages, to meet the preferences of their core electoral clientele (Giger et al., 2011; Mueller \& Bernauer, 2018).

The final issue I cover is how this dynamic of increasing national centralization, constrained, to an extent, by partially autonomous cantonal branches, has impacted on members on the ground. Given this changing context, it is legitimate to ask what rights individual members have to shape what the party does and its choice of candidates and leaders. This will be the topic of the next section, which will focus on internal democracy within the SVP.

\subsection{Internal Democracy: Do Ordinary Party Members Have a Say?}

The members' Delegate Assembly is defined as the supreme party organ by the SVP's (2018) statute. The assembly approves the party programme and statutes, makes final decisions on launching referendums, and elects party leaders. However, it is only marginally involved in the decision-making processes and discussions that precede the act of voting on these matters. In other words, the role of the Delegate Assembly is ambiguous. Several representatives mentioned that they are happy when delegates engage because it fosters the SVP's proclaimed bottom-up process (see representatives $13,18,19$, and 29). Certain matters, such as the development of the party's strategy or programme, are often decided by leadership committees and subsequently approved by the delegates. However, similar decision-making structures apply to other parties as well. According to some SVP interviewees, this procedure avoids long discussions, facilitates consolidated proposals, and "reduces reaction time" (see representatives 2 and 11). Therefore, ordinary members do have a say in certain areas, but their power is limited.

Another aspect is the cantonal representation at the National Delegate Assembly. Members of larger cantonal branches have a bigger influence in the national assembly because these cantons can send more delegates (SVP Schweiz, 2018). This procedure points towards a territorial concentration of power within stronger cantons and potentially undermines equal influence of all cantonal branches. All four parties represented in the national government award such prerogatives to larger and powerful cantonal branches. Unfortunately, it is almost impossible to verify the extent to which cantons exercise their advantageous influence, because detailed protocols of delegate assemblies are not publicly available for every party.

At the cantonal level, a similar mechanism applies to all parties represented in the national government. In the cantons of Bern and Zurich, larger districts or sections send more delegates to the cantonal delegate assemblies, which disproportionally increases their influence. However, in Geneva, the situation is different. Whereas the SP, FDP, and CVP in Geneva employ a similar proportional model as their cantonal branches in Zurich and Bern, the SVP invites all members to attend the cantonal Delegate Assembly and grants them a right to speak. However, this more inclusive approach may be partially grounded in the small number of SVP members in Geneva (300).

At the local level, representatives from all parties endeavour to listen to ordinary members. Within the SVP, several representatives emphasized that they attempt to include party members in decision-making processes during local assemblies (see representatives 10, 13, 15, and 16). They are also personally accessible to members but do not always possess the resources to set up formal debates or roundtables with constituents.

Generally, the SVP highlights the importance of its Delegate Assembly (SVP Schweiz, 2018) but a closer look reveals that the influence of ordinary members within the party is somewhat limited in certain cantonal branches. Interviews with representatives illustrate, however, that ordinary members may also not necessarily be very keen to engage in the party's decision- 
making procedures. As a representative (1) from Zurich described it:

It is difficult to find enough members who want to be delegates and want to go to the Delegate Assembly. It depends on the topic, location, time, and how early the assembly was announced. But it is not easy to motivate and find members who actually attend the assemblies.

\section{Conclusion}

Switzerland is a country with strong social and cultural cleavages and relatively weak national parties (Ladner, 2006). Despite the country's small size, it is characterized by different language regions, varying degrees of urbanization, and a history of religious strife. The polity is kept together by a federalist political structure with predominantly autonomous sub-national entities. Not surprisingly, therefore, decentralization has been a common feature of the organization of Swiss political parties. Yet despite all this, in recent years the SVP has become more centralized, by strengthening the role of national party organs at the expense of cantonal branches and delegate assemblies. The SVP also managed to establish its organization in all cantons across Switzerland and draws on certain aspects close to the mass party model to strengthen its political competitiveness (Mazzoleni \& Rossini, 2016).

Mass parties seek to preserve collective identities through ideology (Panebianco, 1988). In this sense, the shift towards more centralization, as well as the radicalization of the party's ideology in the 1990s, were both inspired by Blocher and his allies. The party achieved a high level of coherence and efficiency under his de facto leadership and did not sustain much damage after the split of 2007. The largest party in the country for many years, the SVP presents itself as the only party willing to stand up to the classe politique made up of the same parties with which it shares power in the federal executive. Today, its clearly defined populist radical right ideology and professional campaigns help foster a strong identity within the party, binding members to it as a community of like-minded people sharing political aims. Focusing relentlessly on its key topics of anti-immigration, the market economy, and anti-EU integration, the SVP shapes a collective identity based on a common ideology that provides the foundation for the community of its members.

Another important feature of mass parties is the development of an active grassroots following and strong organizational centralization (Mazzoleni \& Rossini, 2016). The interaction of the centralized national organization with the network of local sections is important to grow an active base that helps achieve electoral success, by reaching out to the electorate at large. As we have seen, the SVP's executive committee and the Head Office occupy central positions and have far-reaching powers. Moreover, and like other parties, the largest cantonal branches are particularly influential within national bodies when compared to the smallest ones. In this context, the SVP's centralization appears to restrict vertical links with local branches and inputs from ordinary members but, according to representatives' statements, grassroots at the local level still matter (Mazzoleni \& Rossini, 2016). There is now room for further research into the extent to which ordinary members feel underrepresented (if they do) and how powerful cantonal branches exert their influence during national assemblies at the expense of the smallest ones.

Overall, the provision of a clearly articulated ideology and communitarian incentives helps the party attract activists, but further centralization of decision-making processes may lead to an erosion of vertical ties between the national leadership and cantonal branches. In other words, while the SVP comes across as an efficient and well-organized machine that benefits greatly from investing in the structures of the mass party, it also needs to be careful not to alienate its sub-national branches (which are at the forefront of member recruitment and mobilization), and make sure members feel they have ways to influence the message and direction of the party.

\section{Acknowledgments}

The support of the Economic and Social Research Council (ESRC) is gratefully acknowledged (Grant Ref: ES/R011540/1). Where international publication takes place, the attribution should be to the Economic and Social Research Council (UK).

\section{Conflict of Interests}

The author declares no conflict of interests.

\section{Supplementary Material}

Supplementary material for this article is available online in the format provided by the author (unedited).

\section{References}

Albertazzi, D. (2008). Switzerland: Yet another populist paradise. In D. Albertazzi \& D. McDonnell (Eds.), Twenty-first century populism (pp. 100-118). Palgrave Macmillan.

Albertazzi, D. (2016). Going, going,... not quite gone yet? "Bossi's Lega" and the survival of the mass party. Contemporary Italian Politics, 8(2), 1-16.

Albertazzi, D., \& McDonnell, D. (2015). Populists in power. Routledge.

Bernhard, L. (2015). The 2015 Swiss federal elections: The radical right strikes back. West European Politics, 39(4), 879-889.

Bernhard, L. (2017). Three faces of populism in current Switzerland: Comparing the populist communication of the Swiss People's Party, the Ticino League, and 
the Geneva Citizens' Movement. Swiss Political Science Review, 23(4), 509-525.

Betz, H. H. (2013). Mosques, minarets, burqas and other essential threats: The populist right's campaign against Islam in Western Europe. In R. Wodak, M. KhosraviNik, \& B. Mral (Eds.), Right-wing populism in Europe: Politics and discourse (pp. 71-89). Bloomsbury.

CVP Schweiz. (2020). Die Statuten der CVP Schweiz. https://www.cvp.ch/sites/default/files/Statuten_ 2013-d.pdf

Engesser, S., Ernst, N., Esser, F., \& Büchel, F. (2017). Populism and social media: How politicians spread a fragmented ideology. Information, Communication \& Society, 20(8), 1109-1126.

FDP Schweiz. (2020). Statuten. https://www.fdp.ch/ fileadmin/documents/fdp.ch/pdf/DE/Partei/ Statuten/2021_Statuten_FDP_Die_Liberalen.pdf

Federal Council. (2020). Decision-taking at meetings of the Federal Council. https://www.admin.ch/gov/en/ start/federal-council/tasks/decision-making.html

Gerbaudo, P. (2018). Social media and populism: An elective affinity? Media, Culture \& Society, 40(5), 745-753.

Giger, N., Müller, J., \& Debus, M. (2011). Die Bedeutung des regionalen Kontexts für die programmatische Positionierung von Schweizer Kantonalparteien [The importance of the regional context for the programmatic positioning of Swiss cantonal parties]. Swiss Political Science Review, 17(3), 259-285.

Hildebrand, M. (2017). Rechtspopulismus und Hegemonie. Der Aufstieg der SVP und die diskursive Transformation der politischen Schweiz [Right-wing populism and hegemony: The rise of the SVP and the discursive transformation of Swiss politics]. Transcript Verlag.

Klinger, U., \& Russmann, U. (2017). "Beer is more efficient than social media" - Political parties and strategic communication in Austrian and Swiss national elections. Journal of Information Technology \& Politics, 14(4), 299-313.

Kriesi, H., Lachat, R., Selb, P., Bornschier, S., \& Helbling, M. (2005). Der Aufstieg der SVP. Acht Kantone im Vergleich [The rise of the SVP. Eight cantons in comparison]. NZZ Libro.

Ladner, A. (2006). Politische Parteien [Political parties]. In U. Klöt, P. Knoepfel, H. Kriesi, W. Linder, Y. Papadopoulus, \& P. Sciarini (Eds.), Handbuch der Schweizer Politik [Handbook of Swiss politics] (Vol. 4, pp 317-343). NZZ Verlag.

Mazzoleni, O. (2008). Nationalisme et populisme en Suisse: La radicalisation de la "nouvelle" UDC [Nationalism and populism in Switzerland: The radicalisation of the "new" UDC]. Presses Polytechniques et Universitaires.

Mazzoleni, O., \& Rossini, C. (2016). The Swiss People's Party: Converting and enhancing organization by a new leadership. In R. Heinisch \& O. Mazzoleni (Eds.),
Understanding populist party organization: The radical right in Western Europe (pp. 79-103). Palgrave Macmillan.

Mazzoleni, O., \& Skenderovic, D. (2007). The rise and impact of the Swiss People's Party: Challenging the rules of governance in Switzerland. In P. Delwit \& P. Poirier (Eds.), Extrême droite et pouvoir en Europe [The extreme right parties and power in Europe] (pp. 85-116). Éditions de l'Université de Bruxelles.

Mudde, C. (2007). Populist radical right parties in Europe. Cambridge University Press.

Mueller, S., \& Bernauer, J. (2018). Party unity in federal disunity: Determinants of decentralised policyseeking in Switzerland. West European Politics, 41(3), 565-593.

OSCE. (2019). Swiss Confederation Federal Assembly Elections 2019. https://www.osce.org/files/f/ documents/9/1/425009.pdf

Panebianco, A. (1988). Political parties: Organisation and power. Cambridge University Press.

Rennwald, L., \& Zimmermann, A. (2016). The workers' vote in Switzerland, 1971-2011. Social Change in Switzerland, 4, 1-11. https://doi.org/10.22019/SC2016-00001

Scarrow, S. E. (2015). Beyond party members: Changing approaches to partisan mobilization. Oxford University Press.

Skenderovic, D. (2009). The radical right in Switzerland: Continuity and change, 1945-2000. Berghahn Books.

SP Schweiz. (2020a). Statuten der SP Schweiz [Statutes SP Switzerland]. https://www.sp-ps.ch/de/partei/ organisation/delegiertenversammlung/statuten

SP Schweiz. (2020b). Schlussdokumentation Digitale Delegiertenversammlung 27. Juni 2020 [Final documentation digital delegates assembly 27 June 2020]. https://www.sp-ps.ch/de/partei/organisation/ delegiertenversammlung/digitaledelegiertenversammlung

SRF. (2019a). Delegiertenversammlung der SVP-Albert Rösti: "SVP braucht keine Wertediskussion" [SVP delegate assembly Albert Rösti: "The SVP does not need a discussion on values."]. https://www.srf.ch/ news/schweiz/delegiertenversammlung-der-svpalbert-roesti-svp-braucht-keine-wertediskussion

SRF. (2019b). Am Schluss gewinnt, wer mobilisieren kann [In the end, the winner is the one who can mobilise]. https://www.srf.ch/news/schweiz/wahlen-2019/ wahlbarometer/die-waehlerwanderungen-amschluss-gewinnt-wer-mobilisieren-kann

Stockemer, D. (2018). The rising tide: Local structural determinants of the radical right-wing vote in Switzerland. Comparative European Politics, 16, 602-619.

Storz, A., \& Bernauer, J. (2018). Supply and demand of populism: A quantitative text analysis of cantonal SVP manifestos. Swiss Political Science Review, 24(4), 525-544.

SVP Bern. (2019). Statuten SVP Kanton Bern [Statutes SVP Canton of Bern]. https://www.svp-bern.ch/wp- 
content/uploads/sites/18/Statuten-2019-01-15.pdf

SVP Schweiz. (2018). Die Statuten der SVP Schweiz [Statutes SVP Switzerland]. https://www.svp.ch/ wp-content/uploads/Statuten_2018_DE-mitUnterschriften.pdf

SVP Schweiz. (2019a). Neues Parteiprogramm der SVP: Frei und sicher für unsere Schweiz [New SVP party programme: Free and secure for our Switzerland]. https://www.svp.ch/news/artikel/ medienmitteilungen/neues-parteiprogramm-dersvpfrei-und-sicher-fuer-unsere-schweiz

SVP Schweiz. (2019b). Rechnung 2018/Budget 2019 [Account 2018/Budget 2019]. https://www.svp.ch/ wp-content/uploads/Rechnung_2018_Budget2019_
PLA.pdf

SVP Zürich. (2019). Schweizerische Volkspartei des Kantons Zürich; Statuten [Swiss People's Party Canton of Zurich; Statutes]. https://www.svp-zuerich.ch/wpcontent/uploads/sites/23/statuten-kantonalparteizuerich.pdf

Swiss Federal Statistical Office. (2019). Nationalratswahlen [National council elections] https://www. bfs.admin.ch/bfs/de/home/statistiken/politik/ wahlen/nationalratswahlen.html

UDC Genève. (2018). Statuts de I'Union Démocratique du Centre-Genève [Statutes SVP Geneva]. https://www.udc-ge.ch/parti/statuts-de-luniondemocratique-du-centre-geneve

\section{About the Author}

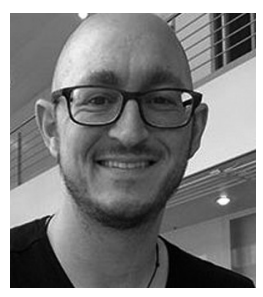

Adrian Favero is a research fellow at the University of Birmingham. He is currently working on an ESRC funded project "The Survival of the Mass Party: Evaluating Activism and Participation Among Populist Radical Right Parties (PRRPs) in Europe" (aka "Populism in Action"; ES/R011540/1). He received his $\mathrm{PhD}$ in Politics from the University of Edinburgh. His research explores themes of European integration, party politics, and intra-EU migration. 